NBER WORKING PAPER SERIES

\title{
WHAT FUNDAMENTALS DRIVE WORLD MIGRATION?
}

\author{
Timothy J. Hatton \\ Jeffrey G. Williamson \\ Working Paper 9159 \\ http://www.nber.org/papers/w9159 \\ NATIONAL BUREAU OF ECONOMIC RESEARCH \\ 1050 Massachusetts Avenue \\ Cambridge, MA 02138 \\ September 2002
}

Paper to be presented to the WIDER Conference on Migration, Helsinki (September 27-28, 2002). We are grateful for the contributions from previous collaborations with Ximena Clark. Hatton would like to acknowledge financial support through a British Academy Research Readership and Williamson would like to do the same to the National Science Foundation SES-0001362. The views expressed herein are those of the authors and not necessarily those of the National Bureau of Economic Research.

(C) 2002 by Timothy J. Hatton and Jeffrey G. Williamson. All rights reserved. Short sections of text, not to exceed two paragraphs, may be quoted without explicit permission provided that full credit, including (C) notice, is given to the source. 
What Fundamentals Drive World Migration?

Timothy J. Hatton and Jeffrey G. Williamson

NBER Working Paper No. 9159

September 2002

JEL No. F22, J1, O15

\section{$\underline{\text { ABSTRACT }}$}

OECD governments note rising immigration with alarm and grapple with policies aimed at selecting certain migrants and keeping out others. Economists appear to be well armed to advise governments since they are responsible for an impressive literature that examines the characteristics of individual immigrants, their absorption and the consequences of their migration on both sending and receiving regions. Economists are, however, much less well armed to speak to the determinants of the world migrations that give rise to public alarm.

This paper offers a quantitative assessment of the economic and demographic fundamentals that have driven and are driving world migration, across different historical epochs and around the world. The paper is organized around three questions: How do the standard theories of migration perform when confronted with evidence drawn from more than a century of world migration experience? How do inequality and poverty influence world migration? Is it useful to distinguish between migration pressure and migration ex-post, or between the potential demand for visas and the actual use of them?

Timothy J. Hatton Department of Economics University of Essex

Colchester, UK and CEPR
Jeffrey G. Williamson

Department of Economics

216 Littauer Center

Harvard University

Cambridge, Mass. 02138

and NBER

jwilliam@kuznets.fas.harvard.edu 


\section{Introduction}

Stories about foreign migrants - legal, illegal and asylum seekers -- appear almost daily in the news. Governments in Europe, North America and Australia note these events with alarm and grapple with policy reforms aimed at selecting certain migrants and keeping out others.

Economists appear to be well armed to advise the debate since they are responsible for an impressive literature that examines the characteristics of individual immigrants, their absorption and the consequences of their migration on the sending and receiving regions involved.

Economists are, however, much less well armed to speak to the determinants of the migration flows that give rise to public alarm.

This paper offers a quantitative assessment of the economic and demographic fundamentals that drive world migration, not just in one country or at one point in time but across different historical epochs and around the world. The paper is organized around three questions:

- How do the standard theories of migration perform when confronted with evidence drawn from more than a century of world migration experience?

- In an intentional effort to reverse the Stolper-Samuelson causal direction that has become so common in modern debate, how do inequality and poverty influence international migration?

- Is it useful to distinguish between migration pressure and migration ex-post, or between the potential demand for visas and the actual use of them?

The next section provides some background motivation. We then outline a basic theoretical framework to guide us through the specification and interpretation of models that explain rates of international migration. Drawing on our previous research, we examine the key economic and demographic fundamentals that drove the European mass emigration in the half-century before 1914. Having identified the fundamentals that drove world migration in an era when potential migrants were relatively unconstrained by policy intervention, we turn to US immigration over 
the last three decades when policy intervention has been a fact of life. These two examples raise issues about emigration from very poor countries, and so we next turn to migration from and within Africa. Finally, we explore the determinants of migration on a global database and conclude with speculations about the future trends in world migration.

\section{Themes Surrounding World Migration}

There is widespread agreement that globalization has been on the rise in the half century since World War II. "Rising globalization" is interpreted to mean that the mobility of goods and factors across international borders has reached new and unprecedented heights. However, the international mobility of goods and capital is probably no greater than it was a century ago (O’Rourke and Williamson 1999; Lindert and Williamson 2002; Obstfeld and Taylor 2002; O'Rourke and Findlay 2002). In contrast, what used to be "free" world migration has become tightly constrained by tough immigration policies that undoubtedly suppress a vast amount of potential migration that might otherwise have taken place (Chiswick and Hatton 2002).

Evidence compiled by the United Nations suggests that the number of people around the world who were living in a country other than the one in which they were born rose from 75 million in 1965 to 120 million in 1990. Although these absolute numbers have certainly increased, world migrants represented just 2.3 percent of world population at both dates (Zlotnick 1998: p. 431). Even if the share increased a bit during the 1990s, these statistics hardly speak of a dramatic increase in globalization as it applies to world migration. Part of the reason that these figures seem inconsistent with common perception is that migrant (foreign-born) stocks in less developed countries have fallen. In any case, the more relevant point is that migrant stocks in the developed world increased from 3.1 to 4.5 percent between 1965 and 1990. In North America, western Europe and Australasia combined, the increase has been even more pronounced, rising from 4.9 to 7.6 percent over the same twenty-five years, an increase of 2.7 percentage points. 
This measure of the rising globalization of world labor markets is certainly impressive, but the rise in these migrant stock shares is still smaller than the rise in the trade/GDP ratio (Findlay and O’Rourke 2002) or the foreign capital/world capital stock ratio (Obstfeld and Taylor 2002).

Another reason why the rise in migrant stock shares has been smaller is that temporary and return migration have become much more common: thus, gross flows have increased faster than net flows.

No matter how the ex-post world migration figures are interpreted, migration pressure seems to have been on the increase. One indicator is the long queues of applicants for immigration to developed countries. In 1994 the waiting list for admission to the United States totalled 3.6 million (Smith and Edmonston 1997: p. 45). Another obvious symptom of this pressure is the surge in illegal immigration, most prominently across the southern border of the United States and into western Europe from the east and the south. About 300,000 illegal immigrants enter the US every year while 400,000 to 500,000 enter western Europe. It is estimated that illegals add ten or fifteen percent to the stock of foreign-born in OECD countries. Another symptom is the rise in those seeking asylum in developed countries. According to UNHCR statistics there were 560,000 asylum applications to 28 industrialized countries in 2000 , with about a million awaiting decision. These figures have soared in the last 20 years and it seems clear that the demand for asylum has increased far faster than the supply of visas offered these refugees. ${ }^{1}$

So why has the pressure on world migration been on the rise? What economic and demographic fundamentals have been at work? Do we expect those fundamentals to rise even more in the future, or to abate?

\footnotetext{
${ }^{1}$ There were 650,450 asylum applications in 1982-6 for 17 countries in western Europe, rising to 1,931,900 in 1997-2001. For the same periods, the number granted refugee status under the 1951 Geneva Convention rose from 183,550 to 221,200, while those granted humanitarian status outside the Convention rose from 27,200 to 206,050. Thus acceptances under these two headings accounted for a third of applications in 1982-6 but only a quarter in 1997-2001.
} 
A wide variety of approaches have been used to attack these questions (Massey et al. 1993), but the underlying theory used in seeking answers often has its shortcomings. We have tried to improve the quality of the answers in three ways. First, most of the theories of migration which all of us find useful deal with a world without immigration controls. This serious shortcoming can be repaired only if we can figure out how to integrate policy into migration models, and then to estimate what difference it would make to our predictions. What makes this agenda so difficult is that immigration policy is itself endogenous, probably influenced by the same forces that drive world migration pressure. One way to get useful answers to this question about fundamentals is to compare the experience in the age of "free" migration before 1914 with “constrained" migration of more recent times.

Second, the recent empirical literature has focused extensively on the effects of migration selectivity on immigrant outcomes. This literature examines the qualifications and labor market quality of immigrants upon arrival, and their subsequent economic assimilation relative to the native-born. Assimilation experience is seen as reflecting the effects of economic incentives and immigration policy on the selectivity of immigrants by individual attributes and country of origin. This literature has been long on examining immigrant labor market performance but short on verifying the underlying model of migration by which this performance is interpreted.

Third, it is often observed that emigration from poor countries increases as economic development takes place in the source country. This was certainly true of the nineteenth century (Hatton and Williamson 1998: Ch. 3), and a glance at the immigration statistics of OECD countries today confirms that the poorest countries typically generate fewer emigrants than those that are further up the per capita income ladder. This common observation does not seem to be consistent with the notion that migration is driven by the gap between income at home and abroad. Instead, observers have detected a hump-shaped relationship between economic development at home and emigration (Massey 1988; Hatton and Williamson 1998: Ch. 3; Stalker 2000: Ch. 7): thus, emigration rates out of really poor countries are very low, while they are much 
higher out of moderately poor countries. One possible explanation for the paradox is that the structural and demographic changes coincident with industrialization generate more migration in early stages than later on. Another, not necessarily competing, explanation is that poverty constrains migration since financing investment in a long-distance move is difficult for the very poor. Thus, any "catching up" increase in incomes at home serves to relax the poverty constraint on emigration, and this positive effect may dominate the negative effect associated with any narrowing of the income gap between home and abroad.

\section{Migration Theory}

The application of theory to world migration provides a useful guide to the variables that might be expected to influence migration pressure and ex post migration quantities. Important contributions have been made by Sjaastad (1962), Borjas $(1987,1989)$, and others. ${ }^{2}$ In the simplest framework, the decision of individual $i(i=1 \ldots \mathrm{n})$ in source country $h$ to migrate to destination country $f$ can be expressed as:

$d_{i}=w_{f, i}-w_{h, i}-z_{i}-c>0$

where $w_{f, i}, w_{h, i}$ are the earnings of that individual in destination ( $f$ for foreign) and source ( $h$ for home) countries respectively, $z_{i}$ is the individual's compensating differential in favor of $h$, and $c$ is the direct cost of migration. This comparison can be viewed in terms of utility if, for example, utility is logarithmic and the variables are expressed as natural logs. Clearly, individual $i$ is more likely to migrate the higher is the destination wage and the lower are the home wage, the compensating differential, and the fixed migration cost. If the first three terms are interpreted as

\footnotetext{
${ }^{2}$ One important strand of theory considers migration as a household decision rather than an individual decision; e.g. Mincer (1978), Stark (1991). That strand of the literature is not considered here, partly to
} 
present values then the likelihood of migration will decline with the age of individual $i$ as the remaining working life becomes shorter. Thus, for a given incentive, migration will be higher the more the source population is skewed towards the younger working ages.

The recent literature has focused on other elements of selectivity in migration. Let individuals in the source country have skill levels indexed by $s_{h, i}$, with mean $\mu_{s h}$ and variance $\sigma_{s h}^{2}$. Incomes at the destination and the source are represented respectively as:

$w_{f, i}=\alpha_{f}+\beta_{f} s_{i} ; \quad w_{h, i}=\alpha_{h}+\beta_{h} s_{i}$

with means and variances, respectively, $\mu_{w f}, \mu_{w h}, \sigma_{w f}, \sigma_{w h}$. Substituting into (1):

$d_{i}=\alpha_{f}-\alpha_{h}+\left(\beta_{f}-\beta_{h}\right) s_{i}-z_{i}-c$

Thus, migration will increase with skill-level (migrants will be positively selected) if the return to skills is greater in the destination than the source $\left(\beta_{f}>\beta_{h}\right)$, and migration will decrease with skill level (migrants will be negatively selected) if the return to skills is greater in the source.

Following Borjas (1989), if $s_{i}$ and $z_{i}$ are normally distributed the migration rate from the source country to the destination can be expressed as:

$D=1-\Phi \frac{\left(-\mu_{w f}+\mu_{w h}+\mu_{z}+c\right)}{\sigma_{d}}$

where $\mu_{z}$ is the mean of $z_{i}, \sigma_{d}$ is the standard deviation of $d_{i}$, and $\Phi$ is the cumulative distribution function of the standard normal. Because $\sigma_{d}$ is a function of the variances of the source and destination wage distributions, $\sigma_{w f}$ and $\sigma_{w h}$, (and therefore of the underlying parameters $\beta_{f}$ and $\beta_{h}$ ),

maintain simplicity and partly because the empirical sections that follow deal with aggregate migration, not 
the migration rate depends on the wage distributions as well as on their means, with an effect that will be non-monotonic. If the destination is "richer" than the source (in the sense that $\mu_{w f}>\mu_{w h}+$ $\left.\mu_{z}+c\right)$, it can be shown that the migration will be an inverse 'u' shaped function of $\sigma_{h} / \sigma_{f}{ }^{3}$

Note that there is no separate effect for the average skill level $\left(\mu_{s h}\right)$ in this model, unless it appears for reasons not considered so far. However, the destination wage or income variable often used in empirical studies is typically the average for all workers at the destination; not the average wage that would be received by the source country workers, if employed in the destination. The former can be written as:

$\mu_{w f}=\mu_{w f}^{*}-\beta_{f}\left(\mu_{s f}-\mu_{s h}\right)$

where $\mu_{w f}^{*}$ is the mean wage of the destination workforce and $\mu_{s f}$ is their mean skill level. If (5) is substituted into the migration equation (4) then relative skill levels will matter with an effect that reflects the return to skills at the destination.

Much of the literature suggests that non-economic factors are important in migration decisions. Such effects are represented here in the individual-specific compensating differential $z_{i}$. One important influence on $z_{i}$ is the stock of previous migrants from the source country living in the destination - the so-called friends and relatives effect. The effects of social networks on migration have been widely studied but they should not be viewed as some alternative to the economic model of migration. Consider two economic interpretations of the friends and relatives effect. One is that it increases destination-specific utility, perhaps also reducing the loss of ethnic

\footnotetext{
distinguishing between households and individuals.

${ }^{3}$ In the case where $s_{i}$ and $z_{i}$ are independently distributed the maximum occurs at the point where $\sigma_{h} / \sigma_{f}=1$. The effects of income distribution have rather different effects in the analysis of Stark and Taylor (1991). They posit that migration is positively related to the degree of relative deprivation among potential migrants at the source. In this case only income inequality at the source should matter and it should have a monotonically positive effect on the probability of migration. For migration within and from Mexico (to the
} 
capital that might otherwise be incurred in migration. The second interpretation is that immigrant networks reduce migration costs directly, implying an individual-level reduction in $c$. The immigrant network can relax the poverty constraint on potential migrants by providing access to loans or outright gifts.

A key feature of migration decisions is the presence of policies that restrict immigration to destination countries. They can be thought of as two types: quotas that restrict numbers (by source country or in total) or policies that select immigrants according to certain characteristics (with or without a cap on numbers). Both can be seen as raising the costs of immigration. In the former, competition for visas raises costs both directly and through queuing. In the latter, the costs are those associated with the acquisition of the relevant characteristics. Two key elements of immigration policy are family reunification and selection by skill. Adding these policy-related components of costs, the individual's decision can be represented as:

$d_{i}=w_{f, i}-w_{h, i}-z_{i}-c^{*}+v_{i}$

Here the fixed cost of migration $c$ has been modified (now denoted $\mathrm{c}^{*}$ ) to include the costs imposed by immigration policy and the additional term $v_{i}$ reflects the lowering of immigration costs associated with individual characteristics. If the individual has close relatives at the destination then this will raise the value of $v_{i}$. If immigration policy is skill-selective then $v_{i}$ will be a function of the individual's skill level. Thus the aggregate migration rate will depend on average skill-level independently of the effects operating through source and destination earnings. ${ }^{4}$

US) Stark and Taylor obtained an inverse ' $u$ ' shaped relation between their relative deprivation index and the probability of migration to the US - a result they attribute to the poverty constraint (see further below). ${ }^{4}$ The aggregate migration equation (4) can be easily modified to incorporate immigration policy (Clark, Hatton and Williamson 2002: Appendix 1). This alters the (non-monotonic) effects of income distribution on migration such that the maximum occurs where $\sigma_{h} / \sigma_{f}>1$ in the case where policy is positively skill- 
In the presence of high migration costs--imposed by policy or otherwise--potential migrants in poor countries may be constrained by their poverty. For a given (fixed and appropriately normalized) cost threshold $\hat{c}$, the proportion of the population who are constrained would be:

$$
P=\Phi\left(\frac{-\mu_{s}+c^{\wedge}}{\sigma_{s}}\right)
$$

Thus the higher is mean income and the lower is the standard deviation of income, the smaller the proportion of potential migrants that will be poverty constrained. Clearly the poverty constraint is not independent of the migration decision and it would be mitigated by the relaxation of credit constraints, but the most important channel for relaxing the credit constraint it likely to be through remittances from previous migrants.

\section{The Age of European Mass Emigration}

The age of mass migration before the First World War gives us an opportunity to look at the economic and demographic fundamentals that drove international migration in a period of relatively free and unrestricted immigration. More than 50 million migrants departed Europe for the New World between 1820 and 1913. About three fifths went to the United States and the remainder to Canada, South America, Australasia, and southern Africa. In the first three decades after 1846 the figure averaged around 300,000 per annum, doubling in the following two decades, and exceeding a million by the turn of the century. In the first half of the century, Britain was the dominant source of the migrants. These were joined in mid-century by a stream of emigrants from Germany followed by a rising tide from Scandinavia and elsewhere in northwestern Europe.

selective. For an analysis of the effects of skill-selective immigration policy in a household context, see Cobb-Clark (1998). 
Emigration surged from southern and eastern Europe from the 1880s-accounting for most of the increase in total European emigration. It came first from Italy and parts of the Austro-Hungarian Empire and then from the 1890s it included Poland, Russia, Spain and Portugal.

After mid-century the migrants were typically young and single and about two thirds of them were male. More than three quarters of the immigrants entering the United States were aged 16-40, at a time when 42 percent of the US population was in this age group. While the young and single might be more adventurous and enterprising, they certainly had the most to gain from the move. They were also relatively (and increasingly) unskilled, a fact that largely reflects shifts in the origin-country composition of the flow. And, once the mass migration took hold, a large proportion moved through migrant networks to join friends and relatives who had previously migrated to the same destination. Although some moved in response to famines, persecution, and political upheaval, the characteristics of the migrants reinforce the premise that the vast majority moved in response to economic incentives--maximizing the gains and minimizing the costs.

Emigration rates varied widely across Europe in the late nineteenth century. The highest rates were from Ireland, averaging 13 per thousand per annum between 1850 and 1913 . Norway and Sweden had emigration rates approaching five per thousand from 1870 to 1913 , while those from Germany were under two per thousand and France was close to zero. These emigration rates also display different trends. Emigration from Ireland declined from the 1860s, and from Germany and Norway it declined from the 1880s. Almost at the same time emigration from Italy and Spain began a steep ascent, a trend that was halted only by the outbreak of war. A challenge to any theory of migration is to explain not only the differences in average rates of emigration across countries, but also the different trends in these rates. ${ }^{5}$

In a recent study (Hatton and Williamson 1998: Ch. 3), we explained decade-average emigration rates pooled across 12 European countries between 1860 and 1913 as a function of 
four key fundamentals (Table 1). The share of the labor force in agriculture is interpreted as a measure of differential mobility between urban and rural populations. The effect is weakly negative providing a little support for the view that rural populations were less internationally mobile. More important is the wage gap as represented by the purchasing power parity adjusted real wage in the source country relative to that for a weighted average of destinations. Note that these wage data are for homogenous occupations across countries, so there is less need to add a measure of average education or skills (and in any case we have no adequate measure of the return to skills). The effect of the home-to-destination wage ratio is strongly negative and the coefficient implies that, in the long run, a ten percent increase in the wage ratio raised the annual emigration rate by 0.7 per thousand. The birthrate lagged 20 years stands as a proxy for the young adult cohort size. Its effect is positive, and it is large—-suggesting that up to half of additional births ultimately spilled over into emigration. Of course, demographic forces can have two effects on emigration: directly, by raising the young adult share; and indirectly, by glutting the home labor market and thus worsening employment conditions there. Finally, a bigger stock of previous emigrants raised current emigration as the friends and relatives effect would predict: for every 1000 previous emigrants, 20 more were 'pulled' abroad every year.

Some observers have suggested that the typical European country went through an emigration cycle that followed an inverted 'U' shape (Akerman 1976; Massey 1988; Hatton and Williamson 1998). As industrial and demographic revolutions unfolded, emigration rates first rose and then fell. Such a pattern can be detected in our data, although for a number of countries it was abruptly ended by the First World War and the immigration restrictions that followed. This stylized pattern can be explained as follows. Demographic effects, aided by urbanization and the growing migrant stock, were important forces in the upswing of the cycle. Later on, these forces

\footnotetext{
${ }^{5}$ There was a wave of studies in the 1960s and 1970s and these are critically surveyed in Gould (1979). A second wave of studies in the 1990s is represented by some of the contributions in Hatton and Williamson (1994).
} 
weakened and were more than offset by strong convergence of European real wages on those in the New World.

It has been argued that instead of, or in addition to, the forces just mentioned, European emigration patterns were driven by the progressive relaxation of the poverty constraint as economic development raised living standards. Industrialization spread from west to east, as did emigration. Faini and Venturini (1994) found that the sharp rise in Italian emigration from the 1880 s could be explained by rising real wages at home — an effect which dominated the negative influence of the rising home-to-destination wage ratio. In contrast, we could find only very weakly-positive home wage effects in our cross-country panel, probably because it was dominated by observations from the relatively prosperous European northwest where the poverty constraint was less binding than in Italy and where it was also mitigated by loans from friends and relatives who had previously emigrated.

These facts may help explain the contrasting emigration trends in Ireland and Italy-two equally poor countries on the periphery of industrial Europe. In the case of Ireland the famine that ejected a million emigrants produced an emigrant stock abroad that provided the bridge for further waves. The annual emigration rate was 19 per thousand in the 1850 s but it trended downwards as, for the following half century, Irish real wages rose strongly compared with those in Britain and the New World. In Italy, by contrast, gradually rising real wages and the cumulating emigrant stock abroad both served to progressively release the poverty constraint and emigration rose strongly as a result.

\section{What Drives Immigrants to the United States?}

In an age when world migration has become severely constrained by policy, the US has remained the leading destination country. After falling to a low in the 1930s, immigration to the US grew from an annual average of 252,000 in the 1950 s to 916,000 in the 1990 s. This growth 
was accompanied by a radical shift in the source-country composition. In the 1950s, Europeans accounted for more than half of all immigrants and these were overwhelmingly from western Europe (Table 2). The proportion from relatively rich western Europe declined sharply to a mere 5.7 percent in the 1990s while that from relatively poor eastern Europe nearly doubled. The counterpart to the decline in the European share was the rise in the Asian share which exceeded a third in the 1970s and 1980s - another shift from rich to poor immigrant source - and a rise in the share from the American continent which increased from 40 percent in the 1950 s to 50 percent in the 1990s. Within the Americas the decline in the proportion from rich Canada was more than compensated by increases from poor Central America, the Caribbean and especially Mexico. The poorest continent, Africa, accounts for only a small share of US immigrants although that share has grown rapidly.

Policy has been important. The dominance of Europe was reinforced by national origins quotas until the 1960s. They were originally introduced in 1921 and 1924, and they strongly favored the countries that dominated the inflow during the nineteenth century, particularly Britain, Ireland and Germany. The 1965 amendments to the Immigration Act abolished the national origins criteria, replacing it with separate quotas for the western and eastern hemispheres, and with a system of preferences that emphasized family reunification. The hemispheric ceilings were combined into a worldwide quota in 1979. The Immigration Reform and Control Act of 1986 introduced mass legalization of immigrants who had resided in the US since 1982. Finally, the 1990 Immigration Act (effective 1992) raised the overall immigration quota and introduced a new system of preferences that allocated a larger share of available visas by occupational attributes rather than by family reunification.

Repeating a contentious debate that took place from the 1890s to WWI, there has been much modern debate about the changing composition of US immigrants and its impact. It has been forcefully argued that the labor market quality of successive cohorts of immigrants, as reflected in education levels, entry wages, and rates of assimilation, declined between the 1950s 
and the 1980s (Borjas 1987, 1994, 1999), just as it was argued that the quality of US immigrants fell between the 1870s and WWI (Hatton and Williamson 1998). This modern trend is seen largely as the result of the 1965 Amendments that abolished the quotas. Opening the door to poorer parts of the world produced a much larger pool of potential immigrants for whom the income gains far outweighed compensating differentials favoring the home country. As a result of their lower skill levels, the new immigrants were located further down the US income distribution than were previous immigrants. More speculatively, to the extent that the return to skills (as reflected in income inequality) was greater in source countries than in the US, there would be negative selection from within each source country, ${ }^{6}$ reinforcing the downward trend in the skills of the average US immigrant. Earlier postwar waves of European immigrants, coming from countries with income distributions more equal than the US, should have been positively selected. Finally, an immigration policy which favored family reunification, gradually lowered the costs of immigration for successive cohorts of migrants from these 'new' source countries. Thus, US immigration policy had exactly the opposite impact intended: it served to hasten the switch in immigrant source towards poorer countries.

The most lively debate on US immigration has been about assimilation outcomes. Although the framework used in these studies is underpinned by the migrant selection model, the determinants of the immigration flow itself have been comparatively neglected. Thus, it is unclear to what degree the forces that drive US immigration are consistent with the interpretations placed on assimilation outcomes. Existing studies of the determinants of immigration by source country have failed to test properly the specification implied by the theoretical discussion above. ${ }^{7}$

\footnotetext{
${ }^{6}$ Ramos (1992) finds evidence for negative selection among migrants to the US from Puerto Rico and for positive selection among return migrants. However Chiswick (2000) has argued that a fixed migration cost will be larger in proportion to the prospective gains for low skilled migrants, leading to positive selection. Funkhauser (1992) finds this to be the case for prospective illegal immigrants from El Salvador: given the high fixed cost, the net gains are greater for those with higher education.

${ }^{7}$ There is, however, an extensive literature originating with Nakosteen and Zimmer (1980) that estimates migration and wage equations simultaneously in the context of inter-regional migration. Ramos (1992) uses this approach for migration from Puerto Rico to the US, although here too there are no immigration controls.
} 
Nevertheless, these studies have provided some useful insights. For a cross section of sourcecountry average emigration rates to the US for 1951-80, Borjas (1987) found that migration was negatively related to source-country income per capita and to source-country inequality. Yang (1995) confirmed the negative source-country income effect in a cross section of emigration rates to the US for the shorter period 1982-6, but found that the stock of previous immigrants was the single most important determinant. More recently, Kamemera et al. (2000) used panel data for the decade 1976-86, including a wide range of variables both for the United States and source countries. Distance, relative income, and US unemployment all mattered, but migration was also positively related to measures of political rights and individual freedom in source countries and negatively related to political instability.

In recent (and ongoing) work with Ximena Clark we have developed a model that attempts to explore these issues more directly. Our dataset is a panel of immigration rates into the US from 81 countries over the years 1971-1998. One variant of this model appears in Table 3. The relative income variable is purchasing power parity adjusted per capita income and, for that reason, relative skill levels are also included as proxied by years of education. These variables produce significant coefficients with negative and positive signs respectively, and they matter quantitatively. For example, the net effect of lower levels of income and education in South America compared to western Europe is to raise the typical South American country's migration rate by 25 percent over that of western Europe. The coefficients on the return to skills, as proxied by relative inequality, also strongly support the Roy model for the case where the destination country is relatively rich. The quadratic peaks with relative inequality at 1.33 , and with an effect that raises immigration from the typical South American country by 46 percent over that of the typical western European country. The share of source country population in the 15-29 age range has a positive effect but its impact is more modest. It raises migration rates from South America by 11 percent over those from western Europe. 
Other variables also have strong effects in the expected direction. Adding a thousand miles to distance from Chicago reduces the migration rate from a country by about a fifth, being landlocked reduces it by more than a third, while being predominantly English speaking raises it by a factor of 3 . The stock of previous immigrants from a source country residing in the US per thousand of the source country population has a significant effect. Evaluated at the mean, the coefficients imply that an addition of 1000 to the migrant stock increases the annual flow of immigrants by 26 - an order of magnitude comparable with that found for nineteenth century Europe (20). The coefficients imply that the stock of previous migrants raises South American migration by 49 percent (high stock to population ratio) compared with East Asia (low stock to population ratio). This difference is itself the cumulative result of past migration rates. History matters.

What about poverty? Here we use a trickling-down proxy for the source country poverty rate -- the ratio of the country's gini coefficient of household income to the square of its income per capita. At a given mean income, a rise in inequality increases the poverty rate, whereas for a given level of inequality, a rise in mean income reduces the poverty rate. ${ }^{8}$ This proxy variable has a negative effect (Pov: Table 3) so that absolute poverty reduces migration to the US. Thus, a rise in source-country per capita income has two effects on US immigration: a negative effect operating through the relative income variable, and a positive effect operating through the poverty variable. ${ }^{9}$ Furthermore, these effects depend on the initial income level. For a typical West European country, a ten percent rise in GDP per capita (holding education constant) reduces migration to the US by 12.6 percent. A ten percent rise in income would reduce migration from the typical East Asian country by 4.3 percent and from the typical South American country by 3.7 percent. But for the typical African country, a ten percent rise in income per capita increases

\footnotetext{
${ }^{8}$ Ravallion (2001) reports an elasticity of the change in the share in poverty with respect to the change in mean private consumption expenditure of around -2 across a set of less developed countries.

${ }^{9}$ We note with interest the recent findings reported by Sala-I-Matin (2002) that poverty rates have been falling world wide since 1960.
} 
migration to the US by 0.3 percent. Looking at the poverty effect alone (i.e. assuming income also rose by ten percent in the US) there would be virtually no effect on the West European country but a 2 percent rise in migration from the African country.

It should be stressed, however, that all of these effects are measured in the presence of a quota on total immigration. Thus while they may be a reasonable guide to the effect of changes in domestic conditions in a single source country, they would be a misleading guide to the effect of world wide changes that would tighten the constraint imposed by the quota. US immigration policy is represented by the variables in the fourth line of Table 3 (plus WH71-6 in the third line). Merging the eastern and western hemispheres after 1976 sharply relaxed the constraint on immigration from eastern hemisphere countries. By contrast the 1990 Immigration Act had marginal effects, even when interacted with relative schooling levels to reflect the shift towards positive selection on skills. Finally the effects of the IRCA legalization program over the years 1989 to 1991 is captured by a variable reflecting the estimated number of source country illegal immigrants residing in the US in 1980. This effect doubled the Mexican immigration rate during those years.

\section{Migration in and from Africa}

By far the world's poorest continent, Africa has generated remarkably few migrants to the major labor-scarce countries despite the massive gains that it would bring to the migrants. True, migration pressure, as reflected by illegal flows between North Africa and southern Europe, has often hit the headlines. Also, the share of Africans in legal immigration to the US has increased. Yet, real incomes in Africa are but a tiny fraction of those in Europe and North America so the incentive to emigrate should be huge. Indeed, the gaps are many times larger than those that gave rise to the mass emigrations from Europe a century ago. 
There are three possible explanations for this apparent paradox. First, OECD immigration policies that stress family reunification or skills impose high hurdles that serve to screen out potential African migrants. This explanation is consistent with the finding that migrant stock effects are large at very low levels. Second, the poverty constraint is sufficiently large to offset the effect of large income gaps for most poor Africans. Third, Africans are simply less mobile than populations elsewhere. We will start with the third of these possible explanations for the paradoxically low African emigration rates to the labor-scarce OECD.

There is, of course, abundant evidence of coerced African migration. Large numbers traveled as slaves across the Atlantic to the Americas from the seventeenth to the nineteenth century. It was not until the 1880s that the cumulative flow of "free" Europeans exceeded that of the coerced Africans (Eltis 1983). More recently Africa has become famous for its refugees. While Africa accounts for a little more than a tenth of world population, it typically accounts for more than a third of the world's stock of refugees living in foreign countries. The number of displaced persons is estimated at about 2.5 percent of the total African population. Typically, these displaced Africans return to their homelands as soon as possible (Rogge 1994) because of political motives, tribal and kinship ties, and the loss of cultural identity (Makanya 1994). Does this suggest an unwillingness to migrate? Probably not since there is a more important force at work: African refugees, often displaced into rural parts of bordering states, experience even greater deprivation than they do at home.

The literature on migration within Africa suggests no lack of mobility. ${ }^{10}$ It is worth citing a few examples. One study of rural Botswana found a highly elastic and positive migration response to wage rates and employment probabilities in the urban sector and a negative response to local wage rates and employment probabilities (Lucas 1985). Another study found that ruralurban migration in Kenya is strongly related to the wage gap and to the individual's education selecting those with higher education as a result of the greater economic return to education in the 
cities (Agesa 2001). But such is not always the case: emigration from Egypt to the Gulf states selected those with few skills and without land. And there is little evidence to suggest that the poorest laborers were constrained from migrating by poverty (Adams 1993: p. 162).

In recent research, we estimated the determinants of net migration to and from countries across sub-Saharan Africa. The migration rates are inferred by demographic accounting where net migration was simply calculated as a residual. Thus, we do not know where emigrants went or where immigrants came from, but the vast bulk of the movements across African borders are not overseas. Still, we have explained these net migration rates, illustrated by the regression in Table 4. The net outward movement of refugees is, of course, an important component of total African cross-border movement although the estimated coefficient is less than one, perhaps because refugees crowd out potential emigrants that would have moved for employment reasons in the absence of the refugees. The share of the home country population aged 15 to 29 also has a positive effect, indicating that a rise of five percentage points in the share of young adults (say from 25 percent to 30 percent of the population) increases annual out-migration by one per thousand.

The relative income variable is the purchasing power parity adjusted unskilled wage rate and hence there is no need to adjust for differences in education. The foreign to home wage ratio has a strong positive coefficient implying that a ten percent rise in the wage ratio increases net out-migration by about one per thousand of the population, an impact similar to that for European emigration a century ago ( 0.7 per thousand). While the growth of domestic output has a negative effect on out-migration, the effect of the growth of output in other economies in the region seems to have little impact. Finally, the poverty constraint, captured here by the inverse of the squared home real wage, has a negative influence, but only significant at the ten percent level, implying that the poverty constraint is weak. At the mean wage rate a ten percent increase in the real wage increases out-migration by 0.2 per thousand, an effect that only partially offsets the one per

\footnotetext{
${ }^{10}$ Valuable collections on African migration include Baker and Akin Aina (1995) and Appleyard (1998).
} 
thousand negative effect operating through the wage ratio. This contrasts with the finding for immigration from Africa to the US where the poverty constraint effect more than offsets the relative income effect. ${ }^{11}$ But since most of the net migration reported in Table 4 is within Africa, it makes sense that the poverty constraint would be a smaller impediment for cross-border movements than it would be for trans-Atlantic migration.

Although these estimates are based on very crude macro data, they do seem to be consistent with micro studies. Findlay and Sow (1998) studied rural households in the Senegal River valley in Mali. They found that the poorer the family, the more likely its migrants would remain in Africa—suggesting that poverty constraints were more important for migration out of Africa. They also found that households with previous emigration experience in France were more likely to send new migrants to France-suggesting that the friends and relatives effect influenced the direction of those migrations. But immigration policy and economic conditions in overseas destinations mattered too.

\section{World Migration}

Despite the disproportionate attention that has been given to immigration pressures on the United States and other OECD countries, there have been other major migration streams around the world. These too have been driven by a combination of demographic and economic fundamentals as well as by political events. In eastern Europe, the collapse of the Soviet regime led to large westward flows in the early 1990s from countries like Romania, Bulgaria, Poland and Russia itself. By 1993 the number of migrants from central and eastern Europe in the European Union (excluding the German ausseidler) had risen to nearly two million (Bauer and Zimmermann 1999: p. 6). These pressures abated somewhat by the late 1990s as the backlog

\footnotetext{
${ }^{11}$ The evidence from Germany also suggests that the poverty trap effect is strong for international migrants from the poorest countries (Rotte and Vogler, 2000).
} 
cleared and conditions in these countries began to improve. Later in the decade, civil war in the former Yugoslavia led to mass outflows, although many of the refugees ultimately returned (OECD 2001a: pp. 68-86).

There have also been major currents of migration in Asia driven by demographic pressures and changing income gaps. Until the middle of the 1980s one of the most important magnets for Asian migrants were Kuwait, Saudi Arabia and the other Gulf states. Mass migration from neighboring countries such as Lebanon, Palestine and Jordan that were also influenced by wars and instability in the region (Shami 1999). The oil-rich states increasingly drew migrants from further afield including East Asia and the Indian subcontinent - a trend that was halted by the Gulf War. The economic miracles by the Asian tigers also resulted in major migration movements. In countries like Korea and Malaysia, persistent net emigration was replaced by twoway streams with falling outflows of natives and rising inflows of foreigners. Such trends were halted, at least temporarily, by the financial crisis of 1997 and the sharp restrictions on immigration that followed (OEDC: 2001b).

Similar forces seem to have been shaping world migration, and it is tempting to see how well a simple migration model might explain them. Based on net immigration inferred from demographic reconstructions, our results are sufficiently encouraging to suggest it would be worthwhile to apply the technique more widely. The UN calculates annual average net immigration rates over five year intervals for most countries. We have used these data to form a panel of five-year periods 1970-1975 to 1995-2000 for 80 countries. The results of this exercise appear in Table 5 .

The share of population aged 15-29 in a receiving country has a negative effect on its immigration, consistent with our findings for immigration to the US and cross-border migration in Africa where a bigger young adult share raises emigration from sending countries. The coefficient implies that a decrease in the receiving country young adult share from, say 30 to 25 percent, would increase its net immigration rate by 0.9 per thousand of the population. This big 
demographic effect is very close to what we found for emigration in sub-Saharan Africa. The immigrant stock has a positive effect on net immigration and its size is consistent with the estimates presented earlier. The coefficient implies that an increase of a thousand in the immigrant stock increases net immigration by about 23 per annum. Refugee movements are captured by a variable measuring the share of years during which the country was embroiled in civil war. This was found to be the most important variable determining refugee displacements across borders in Africa (Hatton and Williamson 2001). Here the effect of a civil war in the receiving region reduces annual immigration (chiefly though refugee outflows) by about 2 per thousand of the population.

Income effects are captured by two education-adjusted relative income terms, one relative to the world as a whole and one relative to the region in which the country is located. These variables are defined as GDP per capita for the country divided by a population-weighted average for the world or the region minus the ratio of education years for the country relative to the world or the region. The restriction that the GDP per capita ratios take equal and opposite signs to the years of education ratios is comfortably accepted by the data. ${ }^{12}$ These two variables represent the effects on total net migration of income gaps relative to the world as a whole and within the region. Both are positive so that a rise in domestic income relative to the world and relative to the region both increase a country's net immigration. A ten percent increase in education-adjusted income raises immigration for the typical country by 0.12 per thousand from the worldwide effects and by 0.09 per thousand for the regional effect. These combined effects are somewhat smaller than those we found previously.

What about the poverty constraint? Here again the poverty constraint is proxied by the gini coefficient of household income divided by the square of GDP per capita. Its effect should be positive on net immigration if greater poverty leads to lower emigration and therefore higher net immigration than otherwise. As before, because of the non-linearity, an increase in mean income 
has different effects at different income levels. For a typical African country, a ten percent increase in education-adjusted income increases net immigration by 0.10 per thousand through the two relative income effects but it also reduces net immigration by 0.16 per thousand. Thus, as was suggested earlier, the effect of increasing incomes at home for the poorest countries, is to increase net emigration (and therefore to reduce net immigration). Africa is the only region where the overall effect of a rise in home income is negative for net immigration. The poverty constraint effect is very small in western Europe, and thus the overall effect of a rise in home income is to increase immigration by 0.31 per thousand. In other regions, the poverty constraint effect is bigger. Thus, for South America the impact of a rise in home income is to increase immigration by 0.13 per thousand; for the Caribbean 0.22 per thousand; and for East Asia 0.20 per thousand.

\section{The Future for South-North and South-South Migration}

Can estimates such as these be used to project the likely pattern of world migration over the next two or three decades? It is important to recognize that the ex post migration streams that we have analyzed are largely conditioned by immigration policies that serve as a filter between the desire to migrate and the migration that actually takes place. The fact that economic and demographic variables strongly influence world migration does not diminish the importance of policy. Future trends are likely to be determined largely by policy choices. However, we can ask how migration pressure is likely to develop. Clearly, if migration pressure increases and policy regimes harden then ex post migration could be lower despite greater migration pressure. In that case we might expect to see further increases in illegal migration, and perhaps a further escalation of policies aimed at combating them.

In our analysis of African migration, we examined the effects of demographic trends on migration pressure in the future. We used UN forecasts of the population size and age structure to

\footnotetext{
${ }^{12}$ The computed $F$ statistic for this restriction is 2.09 compared to the 5 percent critical value of 3.0.
} 
predict net migration rates for African countries into the future, taking account also of their effects on real wage rates. Those projections suggest that migration pressure over the next 20 years should be increasing for demographic reasons alone. Assuming that a mere ten percent of that additional predicted migration spilled out from sub-Saharan Africa, projected annual emigration would increase by about a million between 1995 and 2025 . While the absolute amount of emigration pressure predicted may be debated, the direction of change is more secure. Any prediction must deal with the uncertainties associated with the future course of the HIV/AIDS epidemic, but it still seems clear that the demographic forces that drive African migration will serve as a powerful engine to emigration pressure over the next 20 years.

Since immigration policy in the high-wage OECD and newly industrial countries will play such a central role in the future of world migration, projections are uncertain. What is not uncertain, however, are the economic and demographic fundamentals which have driven the demand for world migration since 1850. To repeat, the big four are: gaps between rich high-wage countries and poor low-wage countries; poverty constraints on the move in poor sending countries; the size of the young adult share in sending and receiving country populations; and the size of the foreign-born migrant stock from the sending counties currently residing in the receiving countries. Three of these are on the rise, driving what might be called South-North migration pressure upwards in the future. First, successful development and poverty eradication in the Third World (Dollar and Kraay 2000; Chen and Ravallion 2001; Sala-i-Matin 2002; Lindert and Williamson 2002) will most certainly release the poverty constraint on potential emigrants from the poorest parts of the world, like China, South Asia, the Asian interior and Africa. Second, while the catching up of canonical labor surplus parts of the world - like China and India - on the OECD (Lindert and Williamson 2002) will reduce the motivation for the move, it looks like Africa will not be part of that catching up. In any case, there may be an unrequited demand for the move which past policy restrictions have choked off temporarily, but is still latent. Third, there is the growing imbalance between the shrinking young adult shares in 
the OECD and the rising young adult shares in South Asia, Africa and other parts of the Third World where the demographic transition has been delayed. This imbalance played an important role in driving world migration in the past, and it should do so in the future too. Fourth, as foreign-born migrants increase as a share of total residents in high-wage countries, the pressure on annual immigration flows will rise too. In short, if OECD countries think they have a immigration problem now, they are going to find the future even more challenging.

We conclude with a word about South-South migration. How long will it be before successful development will shift the target of the emigrating poor from OECD labor markets to those which have recently arrived or shortly will have arrived on the industrial scene? After all, there may be more skills to learn in a newly industrial country's manufacturing job, which is also closer to the poor sending region, than in a post-industrial country's domestic service job, which is also farther away. These opportunities will most assuredly change the direction of South-North flows in a more South-South direction, easing the pressure on OECD migration policy, but creating new problems for the newly industrial country. The future rise of South-South migration will, no doubt, take those analysts who ignore history by surprise. It will not take economic historians by surprise. After all, when those 50 million Europeans left home before 1914, there were at the same time far more than 50 million who left China and India for jobs elsewhere in the periphery. South-South migration is not new. It is just ignored by economists. ${ }^{13}$

\footnotetext{
${ }^{13}$ W Arthur Lewis (1978) had plenty to say about South-South migration, but not many other economists have followed his lead. However, the two of us are starting a South-South migration since 1850 project which we hope will redress the balance.
} 


\section{References}

Adams, R. H. (1993), “The Economic and Demographic Determinants of International Migration in Rural Egypt," Journal of Development Studies 30 (1), pp. 14667.

Agesa, R. U. (2001), "Migration and the Urban to Rural Earnings Difference: A Sample Selection Approach," Economic Development and Cultural Change 49(4), pp. 847-65.

Akerman, S. (1976), “Theories of Migration Research," in H. Rundblom and H. Norman (eds.), From Sweden to America: A History of the Migration (Minneapolis: University of Minnesota Press).

Appleyard, R. (ed.) (1998), Emigration Dynamics in Developing Countries, Vol. I: Sub-Saharan Africa (Aldershot: Ashgate).

Baker, J. and Akin Aina, T. (eds.) (1995), The Migration Experience in Africa (Uppsala: Nordiska Africaininstituet).

Bauer, T. and Zimmermann, K. F. (1999), “Assessment of Migration Pressure and its Labour Market Impact following EU Enlargement to Central and Eastern Europe,” IZA Research Report No. 3.

Borjas, G. J. (1987), “Self-Selection and the Earnings of Immigrants," American Economic Review 77(4), pp. 531-53.

Borjas, G. J. (1989), “Economic Theory and International Migration,” International Migration Review 23(3), pp. 457-85.

Borjas, G. J. (1994), “The Economics of Immigration,” Journal of Economic Literature, 32(4), pp. 1667-1717.

Borjas, G. J. (1999), Heaven's Door: Immigration Policy and the American Economy (Princeton, NJ: Princeton University Press). 
Chen, S. and Ravallion, M. (2001), “How Did the World's Poorest Fare in the 1990s?” Review of Income and Wealth 47 (September), pp. 283-300.

Chiswick, B. R. (2000), “Are Immigrants Favorably Self-Selected? An Economic Analysis,” in C. D. Brettell and J. F. Hollifield (eds.), Migration Theory: Talking Across Disciplines (New York: Routledge).

Chiswick, B. R. and Hatton, T. J. (2002), “International Migration and the Integration of Labor Markets,” in M. Bordo, A. M. Taylor and J. G. Williamson (eds.), Globalization in Historical Perspective (Chicago: University of Chicago Press).

Clark, X.; Hatton, T. J.; and Williamson, J. G. (2002), "Where Do US Immigrants Come From? Policy and Sending Country Fundamentals,” NBER Working Paper 8998, National Bureau of Economic Research, Cambridge, Mass. (June).

Cobb-Clark, D. A. (1998), "Incorporating U.S. Policy into a Model of the Immigration Decision," Journal of Policy Modeling 20(5), pp. 621-30.

Dollar, D. and Kraay, A. (2000), “Trade, Growth, and Poverty.” Unpublished paper. Washington, D.C.: World Bank (October).

Eltis, D. (1983), "Free and Coerced Transatlantic Migrations: Some Comparisons," American Historical Review 88(2), pp. 251-80.

Faini, R. and Venturini, A. (1994), "Italian Emigration in the Pre-War Period," in T. J.

Hatton and J. G. Williamson (eds.), Migration and the International Labor Market, 1850-1939 (London: Routledge).

Findlay, R. and O’Rourke, K. H. (2002), “Commodity Market Integration 1500-2000,” in M. Bordo, A. M. Taylor and J. G. Williamson (eds.), Globalization in Historical Perspective (Chicago: University of Chicago Press).

Findlay, S. and Sow, S. (1998), "From Season to Season: Agriculture, Poverty and Migration in the Senegal River Valley, Mali," in R. Appleyard (ed.), Emigration Dynamics in Developing Countries, Vol. 1: Sub-Saharan Africa 
(Aldershot: Ashgate).

Funkhouser, E. (1992), “Mass Emigration, Remittances and Economic Adjustment:

The Case of El Salvador," in G. J. Borjas and R. B. Freeman (eds.), Immigration and the Workforce: Economic Consequences for the United States and Source Areas (Chicago: University of Chicago Press).

Gould, J. D. (1979), “European Inter-continental Emigration, 1815-1914: Patterns and Causes," Journal of European Economic History 8(3), pp. 593-679.

Hatton, T. J. and Williamson, J. G. (eds.) (1994), Migration and the International Labor Market, 1850-1939 (London: Routledge).

Hatton, T. J. and Williamson, J. G. (1998), The Age of Mass Migration: Causes and Economic Impact (New York: Oxford University Press).

Hatton, T. J. and Williamson, J. G. (2001), “Demographic and Economic Pressure on Emigration Out of Africa," NBER Working Paper 8124, National Bureau of Economic Research, Cambridge, Mass. (February)

Kamemera, D., Oguledo, V. I. and Davis, B. (2000), “A Gravity Model Analysis of International Migration to North America," Applied Economics 32(13), pp. 1745-55.

Lewis, W. A. (1978), The Evolution of the International Economic Order (Princeton, N.J.: Princeton University Press).

Lindert, P. H. and Williamson, J. G. (2002), "Does Globalization Make the World More Unequal?” in M. Bordo, A. M. Taylor and J. G. Williamson (eds.), Globalization in Historical Perspective (Chicago: University of Chicago Press).

Lucas, R. E. B. (1985), “Migration among the Batswana,” Economic Journal 95 (June), pp. 358-82.

Makanya, S. T. (1994), “The Desire to Return,” in T. Allen and H. Morsink (eds.), When Refugees Go Home (London: Africa World Press). 
Massey, D. S. (1988) “Economic Development and International Migration in Comparative Perspective," Population and Development Review 14(3), pp. 383-413.

Massey, D. S., Arrango, J., Hugo, G., Kouaouci, A., Pellegrino, A. and Taylor, J. E. (1993), "Theories of International Migration: A Review and Appraisal," Population and Development Review 19(3), pp. 431-66.

Mincer, J. (1978), “Family Migration decisions,” Journal of Political Economy, 86(5), pp. 749-773.

Nakosteen, R. A. and Zimmer, M. (1980), "Migration and Income: The Question of Self-Selection," Southern Economic Journal 46(3), pp. 840-851.

Obstfeld, M. and Taylor, A. M. (2002), “Globalization and Capital Markets,” in M. Bordo, A. M. Taylor and J. G. Williamson (eds.), Globalization in Historical Perspective (Chicago: University of Chicago Press).

OECD (2001a), Trends in International Migration (Paris: OECD).

OECD (2001b), International Migration in Asia: Trends and Policies (Paris: OECD).

O’Rourke, K. H. and Williamson, J. G. (1999), Globalization and History (Cambridge, Mass.: MIT Press).

Ramos, F. A. (1992), “Out-Migration and Return Migration of Puerto Ricans,” in G. J. Borjas and R. B. Freeman (eds.), Immigration and the Workforce: Economic Consequences for the United States and Source Areas (Chicago: University of Chicago Press).

Ravallion, M. (2001), “Growth, Inequality and Poverty: Looking Beyond Averages," World Bank: Unpublished paper.

Rogge, J. R. (1994), “Repatriation of Refugees,” in T. Allen and H. Morsink (eds.), When Refugees Go Home (London: Africa World Press).

Rotte, R. and Vogler, M. (2000), "The Effects of Development on Migration: Theoretical Issues and New Empirical Evidence," Journal of Population 
Economics, 13(3), pp. 485-508.

Sala-i-Matin, X. (2002), “The Disturbing 'Rise' of Global Income Inequality,” NBER Working Paper 8904, National Bureau of Economic Research, Cambridge, Mass. (April).

Shami, S. (1999), “Emigration Dynamics in Jordan, Palestine and Lebanon,” in R. Appleyard (ed.) Emigration Dynamics in Developing Countries: Vol. IV: The Arab Region (Aldershot: Ashgate).

Sjaastadt L. (1962), “The Costs and Returns of Human Migration,” Journal of Political Economy 70(5, Part 2), pp. S80-S93.

Smith, J. P. and Edmonston, B. (1997), The New Americans: Economic, Demographic and Fiscal Effects of Immigration (Washington DC: National Academy Press).

Stalker, P. (2000), Workers Without Frontiers: The Impact of Globalisation on International Migration (London: Lynne Reinner).

Stark, O. (1991), The Migration of Labor (Oxford: Blackwell).

Stark, O. and Taylor, J. E. (1991), "Migration Incentives, Migration Types: the Role of Relative Deprivation,” Economic Journal 101 (September), pp. 1163-78.

United Nations (2001), World Population Prospects: The 2000 Revision (New York: United Nations).

United Nations (2002), National Population Policies 2001 (New York: United Nations).

United States Department of Justice (2002), 1999 Statistical Yearbook of the Immigration and Naturalization Service (Washington, D.C.: USGPO).

Yang, P. Q. (1995), Post-1965 Immigration to the United States: Structural Determinants (Westport, Conn: Praeger).

Zlotnick, H. (1998), “International Migration, 1965-96: An Overview,” Population and Development Review, 24(3), pp. 429-68. 


\section{Table 1: Regression Estimate for Emigration from Europe, 1860-1913}

$$
\text { MigRate }=-6.08-4.57 \text { AgShare }-6.86 \text { LnWRatio }+0.37 \text { LagBirth }
$$

$$
\text { + 0.22 MigStock + 5.64 Dum; Adj. } \mathrm{R}_{2}=0.69
$$

Note $t$ statistics in parentheses.

Sample Decade-average observations for an unbalanced panel comprising (no of obs): Belgium 1860-

1913 (5); Denmark 1880-1913 (3); France 1870-1913; Germany 1970-1913 (4); Great Britain 1860-

1913 (5); Ireland 1860-1913 (5); Italy 1880-1913 (3); Netherlands 1860-1913 (5); Norway 1880-1913

(3); Portugal 1870-1913 (4); Spain 1890-1913 (2); Sweden 1860-1913 (5).

Variable definitions: MigRate $=$ gross emigration rate per thousand population per decade to all foreign destinations; Agshare $=$ share of labour force in agriculture; LnWRatio $=\log$ of the ratio of purchasing power parity adjusted wage rates, source country to a weighted average of destination countries;

LagBirth $=$ source country birth rate lagged 20 years; Migstock $=$ stock of previous immigrants in destination countries at beginning of decade per thousand of source country population; Dum $=$ dummy for Belgium, Italy, Portugal and Spain.

Method Pooled OLS regression on 48 country/period observations.

Source Hatton and Williamson (1998), column 4, Table 3.3, p. 39.

\begin{tabular}{|lrrrrr|}
\hline Table 2: Source Area composition of US Immigration, 1951-99 & (\% of total) & \\
\hline Region of Origin & $\mathbf{1 9 5 1 - 6 0}$ & $\mathbf{1 9 6 1 - 7 0}$ & $\mathbf{1 9 7 1 - 8 0}$ & $\mathbf{1 9 8 1 - 9 0}$ & $\mathbf{1 9 9 1 - 9}$ \\
Europe & 52.7 & 33.8 & 17.8 & 10.3 & 14.9 \\
$\quad$ West & 47.1 & 30.2 & 14.5 & 7.2 & 5.7 \\
East & 5.6 & 3.6 & 3.3 & 3.1 & 9.2 \\
Asia & 6.1 & 12.9 & 35.3 & 37.3 & 30.8 \\
Americas & 39.6 & 51.7 & 44.1 & 49.3 & 49.7 \\
$\quad$ Canada & 15.0 & 12.4 & 3.8 & 2.1 & 2.1 \\
Mexico & 11.9 & 13.7 & 14.2 & 22.6 & 25.3 \\
Caribbean & 4.9 & 14.2 & 16.5 & 11.9 & 10.8 \\
Central America & 1.8 & 3.1 & 3.0 & 6.4 & 5.6 \\
$\quad$ South America & 3.6 & 7.8 & 6.6 & 6.3 & 5.9 \\
Africa & 0.6 & 0.9 & 1.8 & 2.4 & 3.8 \\
Oceania & 0.5 & 0.8 & 0.9 & 0.6 & 0.6 \\
Total (000's) & 2,515 & 3,322 & 4,493 & 7,338 & 7,605 \\
\hline
\end{tabular}

Source: 1999 Statistical Yearbook of the Immigration and Naturalization Service, Table 2.

Notes: Immigrants classified by country of last residence. Percentages exclude the category "origin not specified". Western Europe is defined as the countries of the European Union, excluding Finland but including Norway and Switzerland. East Europe includes the category "Other Europe". 
Table 3: Regression Estimate for US Immigration, 1971-1998

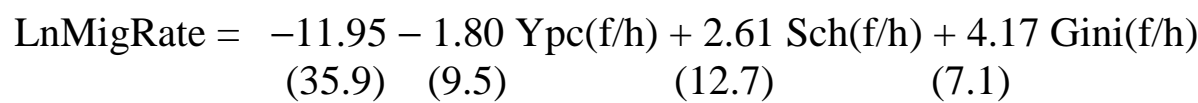

- $1.57\left(\right.$ Gini $(\mathrm{f} / \mathrm{h})^{2}-2.71$ Sp15-29 - 0.18 Dist + 1.11 Englp - 0.31 Landlk

(15.4)

(7.0)

+ 42.91 ImStck - 182.94 (ImStck $)^{2}-0.36$ Pov + 0.06 WH71-6

(6.5)

$(0.8)$

-0.42 EH71-6 - 0.01 D92-8 + 0.14 D92-8*Sch + 0.05 IRCA; $\mathrm{R}^{2}=0.77$

$(0.8)$

Note: robust $t$ statistics in parentheses.

Sample: Balanced panel of number of immigrants to the US by country/year 1971-98. Regional composition (no of countries): Western Europe (16); Eastern Europe (6); East Asia (14); Middle East (5); North America (2); Caribbean (4); Central America (6); South America (11); Africa (14); Oceania (3).

Variable definitions: LnMigRate $=\log$ of the ratio of immigrants admitted by country of birth per thousand of source country population; $\mathrm{Ypc}(\mathrm{f} / \mathrm{h})=$ ratio of GDP per capita at $1985 \mathrm{PPP}$, source country to US; $\mathrm{Sch}(\mathrm{f} / \mathrm{h})=$ ratio of years of schooling for those aged 15 and over, source country to US; Sp15-29 $=$ share of source country population aged $15-29 ;$ Gini $(\mathrm{f} / \mathrm{h})=$ ratio of gini coefficient of household income, source country to US; Dist = great circle distance from Chicago in 1000 miles; Englp = dummy equals 1 if source country is predominantly English speaking.; Landlk = dummy equals 1 if source country is landlocked; ImStck $=$ stock of immigrants in the US from source country per thousand of source country population; Pov = source country gini coefficient/source country income per capita squared; WH71-6 = dummy equals 1 for western hemisphere countries times dummy equals 1 for 1971-6; EH71-6 = dummy equals 1 for eastern hemisphere countries times dummy equals 1 for 1971-6; D92-8 = dummy equals 1 for 1992-98; D92-8*Sch = D92-8 times years of schooling ratio; IRCA = estimated number of illegal immigrants residing in the US in 1980 per thousand of source country population times dummy $=1$ for $1989-91$.

Method: Pooled OLS regression on 2268 country/year observations. Dummies for Canada, Mexico and 8 regions (with Western Europe as the excluded group) included but not reported.

Source: This is a variant of the model presented in Clark, Hatton and Williamson (2002). Further details of data sources and methods are available there. 
Table 4: Regression Estimate for African Net Migration, 1977-95

NetMigRate $=-58.45+0.47$ NetRef $+10.02 \operatorname{LnWRatio}(\mathrm{f} / \mathrm{h})+2.11$ Sp15-29

(2.4) (3.1) (2.9) (2.4)

$-0.53 \operatorname{grY}(\mathrm{h})+0.04 \operatorname{grY}(\mathrm{f})-1.46$ Pov $; \quad \mathrm{R}^{2}=0.53$

(2.0) (0.2) (1.7)

Note: robust $t$ statistics in parentheses.

Sample: Unbalanced panel of country/years comprising: Angola 1982-95; Burundi 1980-5; Cameroon 1980-95; Central African Republic 1989-95; Chad 1980-95; Côte d'Ivoire 1989-95; Gabon 1977-90; Ghana 1977-95; Lesotho, 1981-95; Malawi 1987-95; Mali 1987-95; Nigeria 1977-95; Rwanda 197995; Senegal 1989-95; Sierra Leone 1991-5; Sudan 1984-95; Swaziland 1978-95; Togo 1982-93; Zambia 1981-95; Zimbabwe 1983-95.

Variable definitions: NetMigRate $=$ net out-migration per thousand of population; NetRef $=$ net outflow of refugees per thousand of population; LnWRatio = ratio of real unskilled wage rates at 1990 PPP, foreign to home, where the foreign index is a weighted average regional (0.9) and OECD (0.1) wage rates; $\operatorname{grY}(\mathrm{h})=$ growth rate of real GDP per capita in home country; grY(f) index of growth rate of GDP in the region, where the African regions are west, east, middle and south; Pov = inverse of home real wage squared.

Method: Pooled OLS regression on 265 country/year observations. Dummies for Ghana 1983 and 1985 and Nigeria 1983 and 1985 included but not reported.

Source: This is a variant of the model presented in Hatton and Williamson (2001). Further details of data sources and methods are available there. 


\title{
Table 5: Regression Estimate of Net Immigration for 80 countries 1970-2000
}

\author{
NetMigRate $=2.65-0.18$ Sp15-29 +0.23 ImStck -2.05 CivWar \\ (1.3) (2.3) (7.1) (2.7) \\ + $0.89(\mathrm{YpcW}-\mathrm{SchW})(\mathrm{h} / \mathrm{f})+0.72(\mathrm{YpcR}-\mathrm{SchR})(\mathrm{h} / \mathrm{f})+1.49 \mathrm{Pov}$

$$
\mathrm{R}^{2}=0.26
$$

Note: $t$ statistics in parentheses.

Sample: Balanced panel of five year averages $1970-5$ to $1995-2000$ for 80 countries. Regional composition (no of countries): Western Europe (16); Eastern Europe (6); East Asia (14); Middle East (5); North America (2); Caribbean (4); Central America (6); South America (9); Africa (14); Oceania (3).

Variable definitions: NetMigRate $=$ net immigration per thousand of the population per annum, five year average; Sp 15-29 = percentage of population aged 15-29, five year average; ImStck = percentage of foreign-born in the country, beginning of period; CivWar = proportion of civil war years in period; $(\mathrm{YpcW}-\mathrm{SchW})(\mathrm{h} / \mathrm{f})=$ five year average of ratio of county GDP per capita at $1985 \mathrm{ppp}$ divided by the weighted average GDP per capita of all other countries, minus five year average of ratio of country years of education for those aged 15 and over divided by the weighted average years of education of all other countries; $(\mathrm{YpcR}-\mathrm{SchR})(\mathrm{h} / \mathrm{f})=$ five year average of ratio of county GDP per capita at $1985 \mathrm{ppp}$ divided by the weighted average GDP per capita of other countries in the same region, minus five year average of ratio of country years of education for those aged 15 and over divided by the weighted average years of education of other countries in the region; Pov = average ratio of country gini coefficient divided by per capita income squared.

Method: Pooled OLS regression on 480 country/period observations.

Source: Net migration rates from World Population Prospects: The 2000 Revision, New York: United Nations, 2001. Immigrants stock from National Population Policies 2001, New York: United Nations, 2002. The sources for other variables are as in Clark, Hatton and Williamson (2002). 